\title{
Maurice Godelier and the Metamorphosis of Kinship, A Review Essay
}

\author{
ROBERT H. BARNES
}

Institute of Social and Cultural Anthropology, Oxford

Once it was thought that kinship was the preeminent subject of anthropology, one about which considerable progress was possible. "Kinship" itself was, for some, fairly unproblematic. Thus Radcliffe-Brown (1952: 46) asserted that, "if any society establishes a system of corporations on the basis of kinship ... it must necessarily adopt a system of unilineal reckoning of succession," and Fortes (1959: 209) announced that, "Kinship, being an irreducible factor in social structure has an axiomatic validity." However, in the late 1960s and early 1970s one leading figure of anthropology after the other declared that there really was no such thing as kinship. "The process of making kinship into a single theoretical entity seems to me no better than the invention of 'totemism"” (Terray 1969: 135-36; 1972: 140-41). "There is no such thing as kinship, and it follows that there can be no such thing as kinship theory” (Needham 1971: 5). “'Kinship,' like totemism, the matrilineal complex and matriarchy, is a non-subject since it does not exist in any culture known to man" (Schneider 1972: 59). "The whole notion of 'a kinship system' as an isolable structure of sentiments, norms, or categorical distinctions is misleading because it assumes, or seems to assume, that the ordering principles of a society are partitionable into natural kinds only adventitiously connected" (Geertz and Geertz 1975: 156). For various political and intellectual reasons, "kinship" appeared to many to have died out as an area of analytic interest within anthropology during the 1970s and 1980s, despite many indications to the contrary. Now Godelier has made a major effort to revive attention to matters usually bunched under the phrase "kinship," and, at least as concerns French popular taste, seems largely to have succeeded. For him kinship has not died, but instead transformed itself both in fact and "theoretically."

Métamorphoses de la parenté is an ambitious and expansive exploration of a variety of topics which have been central to anthropology since its inception. To these topics he has added several themes of heightened current social and political interest. The two principal aims of the book are to refute his master 
Claude Lévi-Strauss' theory that society is based on the exchange of women and to refute a recent theory of the origin of incest prohibitions offered by his colleague Françoise Héritier. In the course of his explorations he covers such topics as the transformation of western European relationship systems over a long period of history, socially imposed ritual homosexuality, spiritual and physical theories of conception, Christian theological definitions of incest, the analysis of descent, filiation, and affinity, the kindred, monogamy and polygyny, sexuality, bestiality, the relation between the primates and homo sapiens, the history of the family, and many others. Finally he proposes his own "scenario."

The geographic range of his work is worldwide. He devotes his first chapter to his own experiences during a total of seven years of field research among the Baruya of New Guinea to which he returns later in the book. However, what has attracted interest in France so far has not been his exploration of remote ethnographic issues, but his discussion of homosexual marriage and families in the West taken up in the introduction. Since its appearance the book has rapidly gone through three printing runs and is at the moment difficult to obtain. His introduction and conclusion appear to have provoked most of the interest. In the introduction he reviews an upheaval in kinship and ideas about kinship during the last thirty years of the twentieth century. These transformations include a strong reduction in number of marriages, a pronounced increase in divorce, increase in the number of one-parent families, and families composed of the fragments of previous families. Although conjugal ties have weakened, the desire of parents to continue assuming their responsibilities to their children has not lessened. The nineteenth century moved toward valuing childhood and the child, and in Europe this trend continued even more strongly in the twentieth.

The dimension of alliance weakened, but the dimension of filiation did not. However filiation may not remain what it was because of the development of new reproductive technologies. Previously while it might be said that if there could be doubt about who a child's father was, there could be no doubt about its mother. Today it may be possible to doubt the mother's identity.

In the last twenty years forms of homosexual union have spread which formerly were forbidden and repressed and have tacitly become accepted by public opinion. For the first time these unions contest the genealogical principle. They do so through, on the one hand, a form of marriage and, on the other, in a minority of cases through adoption in order to establish a family.

From these developments a paradox has emerged. Marriage is declining among heterosexuals and emerging among homosexuals. Whereas before the new technologies became available, children sometimes were not wanted, now they are wanted by homosexuals. One partner in such a union may choose to act as father or mother with no reference to biological gender. Godelier poses the question, does this paradox not prove that 
kinship is basically social and not biological, thus confirming a thesis dear to kinship experts?

The preeminent place of anthropology in the study of kinship has thus been confirmed, Godelier concludes, and experts in other fields are now turning to anthropology to answer their questions. However, just at the moment when their advice is needed, the majority of anthropologists have ceased to be interested in the topic. Though kinship was once thought to be the finest flower of anthropology, to which the great names all made a contribution, today it is treated by anthropologists as a non-subject. It is no longer taught in many universities in the United States and in some in Europe. The "postmodernists" rarely mention the topic. However, instead of disappearing, it has just migrated to other domains of anthropology, seized by new questions which reshape it. The analysis of kinship has simply deserted the place where anthropology roamed for decades, entangled in false problems that in principle are insoluble. The voids left by this desertion are not necessarily a sign that the announced death has already taken place.

F R A N C E

Godelier's purposes are comparative and historical, and an important vantage for comparison is Western Europe, particularly France to which he devotes detailed attention in the introduction and elsewhere. As he represents it, French society is and was cognatic in its organization, possessing three elements: the nuclear and monogamous family, the network of families related by ties of consanguinity or affinity, and the kindred focused on the individual and including relatives traceable through various combinations of consanguinity and affinity but with only contingent limits. The extended family existed in some regions, but has practically disappeared. Other elements associated with these three under the Ancien Régime disappeared after the French revolution and the promulgation of the Napoleonic Code, or subsequently. Under the Ancien Régime, marriage was a religious act, a sacrament, and divorce was forbidden by the Church. The father and husband had authority over his wife and children. These configurations began to change with the introduction of the Napoleonic Code in 1804. This code established the institution of civil marriage. In the nineteenth century concubinage continued to be stigmatized, and "natural" children were accorded no legal rights. There were strong social pressures for young people to marry into their "condition," in their milieu. Only the father exercised authority in the heart of the family. He was invested with paternal power, a concept that originated in ancient Rome. The husband had to insure the material existence of the family. A married woman was subject to marital power and was juridically powerless. Marriage, either civil or religious, remained the founding act of the couple. Divorce, which at first was recognized, was abolished in 1816. Premarital sex was repressed. 
Homosexuality was condemned and considered an unnatural desire, as a sin for believers, as a pathology in the eyes of the medical circle, and homosexual couples had to hide their relationship.

In 1970 the notion of paternal power was abolished and parental authority shared equally by husband and wife was substituted for it. Parents were expected to assume responsibility for their children in respect of health, education, security, and morality, even after divorce. Parental authority was considered a matter of public order guaranteed by the state.

By 1975 divorce by mutual consent was instituted in France. In 1996, 38 percent of marriages ended in divorce. There were also a number of separations not involving divorce, such as in the case of concubinage. From this situation arose the multiplication of one-parent families and "recomposed" families, that is, marriage between two previously divorced persons. The prolongation of life in comparison with the nineteenth century allowed people to establish several types of unions during a lifetime. Marriage is more than the establishment of a couple, but it is not sufficient to establish a family, which requires the birth of a child. It would therefore be wrong, Godelier states, to think that marriage has been rejected, when the institution has simply lost its social weight. Negative attitudes toward concubinage have largely disappeared, as has opprobrium placed on children who are the products of such unions.

The networks of related families still exist and continue to provide support to individuals beyond the limits of their natal or conjugal families, above all during periods of economic recession and youth unemployment. But these networks tend to shrink to direct ties of filiation to the exclusion increasingly frequently of distant or close collaterals. The kindred also tends to reduce itself to a small number of consanguineous or affinal relatives with whom the individual chooses to maintain ties.

Among the factors which have modified the forms and exercise of kinship in the last half century, the first is the accent put on freedom of choice of partner, a choice free from social constraints and conventions, such as the obligation to marry into one's own circle, to transmit a name, to perpetuate the family, social group, etcetera. In the choice, desire, love, sentiments from now on prevail over other less subjective and more social considerations. Furthermore, adolescent love is no longer prohibited. All of these facts testify to a new attitude toward sexuality. In this context, the disappearance of love or desire are sufficient reasons henceforth to break up a union and make the individual available for new ties, a new life.

The second factor is the transformation in the relations between men and women, and the social pressure that increasingly exerts itself in favor of greater equality between the sexes in all social and personal aspects of life. Women are also increasingly entering into economic life and make an essential contribution to the material circumstances of their families. They thereby gain increased material autonomy in respect of their partners. 
The third factor is the movement to accord value to the child and childhood, which means that the child is no longer regarded as deprived of reason and becomes a person whose arrival in a family is less and less endured but instead desired, that is to say, thanks to medical progress, planned. The child from now on occupies a large place in the affective and economic life of families. Having a large family is no longer an ideal. The modern model is two working parents with two children, a boy and a girl.

Children become adults at the age of eighteen, and parents have to invent new forms of authority, which aim at convincing rather than being obeyed and depend on dialogue rather than violence. Parenthood has become difficult, and one sees in many families a profound crisis of parental authority, which affects the father more than the mother. As a result in the event of divorce or separation there is a virtual dissolution of the father figure. Some 80 percent of children of divorced or separated parents live with the mother, as opposed to 8 percent who live with their father. Only 20 percent of children living with their mothers see their fathers once a week. Furthermore, if the father or mother remarry, the children find themselves in families composed of fragments of families, where they often have difficulty finding their reference points and place.

From the perspective of history, all the changes affecting kinship belong to a general phase of the evolution of western societies, which are capitalist and privilege the individual, and democratic and reject in principle despotic forms of public and private authority. To these traits are added others coming from the Christian tradition, either because this tradition continues to affect individuals and institutions or because they provoke in reaction specifically Western ruptures in the region of sexuality or family. Civil marriage has become the only legal form of marriage in several European countries, where religious marriage has been relegated to private choice. No one anticipated these changes and no one knows where they are leading. Some deplore these developments. Others feel they live in the first era where individuals can live as they choose unconstrained by prejudices and conventions.

\section{THE BARUYA}

Godelier's explorations of kinship began with his research among the Baruya in 1967. There he encountered in some respects profoundly different issues from those familiar in western European societies. His attempts to understand these matters comparatively eventually led him to a reassessment of developments in the West. In his first months, he began collecting genealogies, his informants being initiated boys and unmarried girls. After some months, he showed his results to adults, who told him that almost everything he had written down was incorrect. His attempts to record relationship terms also not going well, he decided to pursue different issues, namely the production of salt money and gardening. Six months of visiting the gardens transformed 
his relationships with the Baruya who were tirelessly interested in talking about them. Discussing the gardens inevitably led to discussing kinship, war, religion, and history. Returning to kinship, he enlisted the aid of an old woman and a few old men, who were equally interested in expanding their already large knowledge of these matters.

At the age of ten years, a Baruya boy is brutally seized from his mother and handed over to elder, as yet unmarried, boys, whose sperm they must drink in order to be reborn as men, stripped of all traces of having been born of a woman. A girl is not reborn. Descent group membership is strictly patrilineal. Names are transmitted from grandfather to grandson and from grandmother to granddaughter. Their relationship terminology is "Iroquois," that is, indicating neither a rule of descent, nor a marriage prescription, yet being compatible with lineage exogamy, while employing separate terms for relatives through marriage from those used for consanguines. Of course the European distinction between consanguines and affines is itself problematic. A man may not marry his mother's brother's daughter or his father's brother's daughter, but he may marry his father's sister's daughter or his mother's sister's daughter. The exchange of sisters between men is practiced, but two brothers may not take wives from the same lineage. Indeed, remarriage between lineages in the same direction is not permitted for several generations. The Baruya distinguish five types of marriage, namely direct exchange of women between lineages, father's sister's daughter marriage when there has been no such direct exchange, elopement, a rare form of bride service (the husband lives with the wife's parents and assists them) when the husband is an orphan, and occasionally marriage to women of another tribe entailing payment of bridewealth.

The bones, blood, and skin of a Baruya infant are made from its father's sperm. If the vaginal liquids of its mother are stronger than its father's sperm, it will be a girl, if the reverse is true, then a boy. The sun finishes the embryo by supplying the hands, feet, and nose, the seat of intelligence. After the child is at least a year old, its lineage makes gifts to its mother's lineage during a ceremony which ends with its receiving its first name, which is also the first name of an ancestor, with which a portion of the spirit of this ancestor is also transmitted to it. Heterosexual intercourse is a threat to society and the cosmos, endangering the men's force and that of the plants and game that nourishes them. By contrast the sperm which initiated boys give uninitiated boys in the men's house causes their rebirth and contributes to their strength and beauty. A married man may not give his sperm to a boy, because his is already contaminated. Menstrual blood is an antisperm of sorts. The moon, the wife of the sun in popular understanding, but the younger brother of the sun in the esoteric version of the shamans, opens the bodies of the young girls so that their menstrual blood can flow. Underneath their myths lies the men's fear of women and envy of their power to give life, which the men wish to appropriate for themselves. 


\section{DESCENT}

French filiation is commonly used to refer to two different types of relationship, covered in British practice by the terms "descent" and "filiation." Of course French does have the resources to express the same distinction, as descendance and filiation. As Fortes (1959: 207) defined matters, "whereas filiation is the relation that exists between a person and his parents only, descent refers to a relation mediated by a parent between himself and an ancestor, defined as any genealogical predecessor of the grandparental or earlier generation." It would be wrong, of course, to think that British or American anthropologists have all adhered strictly to these definitions. On this matter, in any case, Godelier affirms his allegiance to Anglo-Saxon usage. The utility of the distinction is apparent in a situation such as that of the Talensi of Ghana, who as described by Fortes have corporate patrilineal descent groups. A man also has rights in the patrilineal descent group of his mother through his filiation to her (Fortes 1953: 33).

Godelier provides the following classification of rules of descent, namely unilineal, duolineal or ambilineal, bilineal and non-lineal. This somewhat unfamiliar set of designations need not detain us, as he is simply repeating common anthropological knowledge. Another way to present the same information is to say that there are six possible rules of descent: patrilineal, matrilineal, double unilineal, parallel, alternating and cognatic (Needham 1971: 10; Murdock 1940; 1949: 44-47).

It may well be asked, how can there be more than two rules of descent, if descent is through the parents? A similar mode of thought would suggest that there are only two modes of filiation-patrifiliation and matrifiliation (be it noted Godelier says that filiation is bilateral and cognatic) - as there are only two parents, one male and the other female. Human imagination being what it is, there could well be societies with cultural doctrines which assert that there are more than two genders and that there are more than two parents, a doctrine which would lead to more than two types of filiation and which is not far removed from some of Godelier's considerations on procreation. Be that as it may, as long as opposite sex siblings are treated the same way, there is some sense in saying that there are only two rules of descent, which are either present, absent, or combined, taking care of four of the possibilities listed above, namely patrilineal, matrilineal, double unilineal, and cognatic. At once there is a difficulty. One way to view the cognatic alternative is that it is not a rule of descent at all, but the absence of such a rule, namely descent is neither prescribed through the mother nor through the father. Precisely the opposite view could be taken, namely that it is indeed a rule of descent because it specifies that descent is through one parent or the other. New logical possibilities arise if one abrogates the assumption that opposite sex siblings have the same rule, giving rise to parallel and 


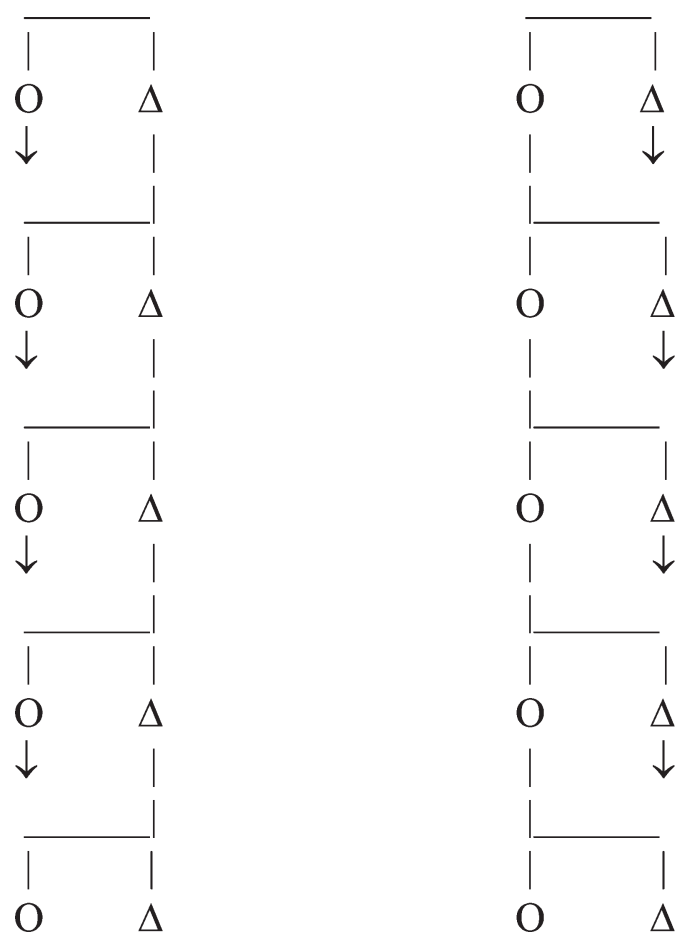

FIGURE 1 Mother's brother to sister's son and father's sister to brother's daughter transmission (after Bamberger 1974: 375, figure 4).

alternating rules. Thus the sex of the child and not just the sex of the parents becomes important for determining outcome. The parallel rule specifies that a boy acquires descent through his father, a girl through her mother. If one wished, one could say that males have a patrilineal rule and females a matrilineal rule. By reversing the allotment of rules, we obtain alternating descent. A male belongs to the group of his mother, a female to that of her father. Strictly speaking, within Fortes' definition of descent, we could say that with alternating descent, a matrilineal rule is applied to a male and a patrilineal rule to a female, but the result is not what we usually expect with unilineal descent, because every generation is of a different sex from the preceding and following, hence the designation alternating.

Needham comments that once the alternating mode is introduced variations on it increase the possibilities, but that his six are the elementary ones. Indeed Bamberger (1974: 371, 374-75) has discovered a rule for transmitting names from mother's brother to sister's son and from father's sister to brother's daughter that can be seen as a variation on parallel descent (see Figure 1). 


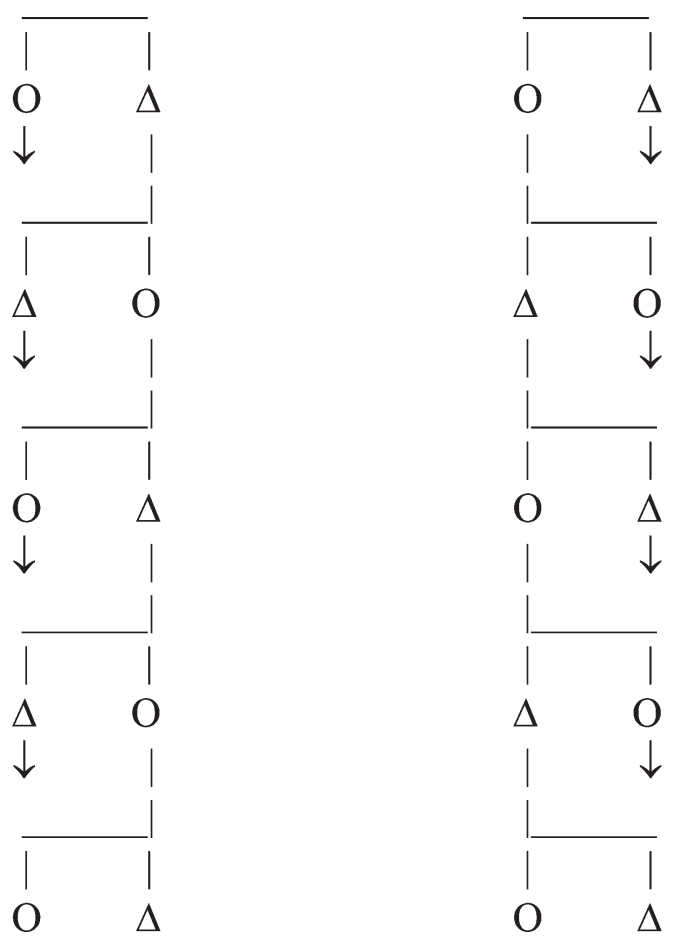

FIGURE 2 Mother's brother to sister's daughter and father's sister to brother's son transmission.

A similar variation on alternating descent would be transmission from mother's brother to sister's daughter and from father's sister to brother's son (see Figure 2). All of the logical possible combinations of the six elementary modes give a total of sixty-three types (Needham 1971: 10-11).

There are many societies that do not employ a rule of unilineal descent, but do have groups, membership in which is acquired through a parent, hence are cognatic in formation. There are many societies with patrilineal descent groups, not so many with matrilineal descent groups, and a few which have descent groups of both kinds. In principle there is no reason why you could not have in the same society patrilineal descent groups, matrilineal descent groups, groups in which membership is obtained through either parent and groups where membership makes no reference to parentage. All that is necessary is that these different kinds of groups be constituted for entirely different purposes. With the parallel and alternating rules we approach the limits of the utility of exploring logical possibilities of rules of descent. Needham (1971: 10-11) says that these modes, "could not be employed socially as regular and exclusive principles of transmission and incorporation, though certain 
rare and uncertain approximations to them have been reported," and Scheffler (2001: 20) has concluded that, "It seems not at all improbable that 'parallel' and 'alternating' forms of 'descent' are wholly anthropological fictions with no genuine ethnographic examples."

Godelier (2004: 105) characterizes double unilineal descent as rare, and the parallel and alternating modes as even rarer. In fact, clearly attested examples of double unilineal descent do exist in various parts of the world. The most frequently cited example is the Yakö of Nigeria (Forde 1950), although there are other such African societies and Scheffler (2001: 122-23) using his own definition denies that the Yakö have patrilineal descent groups and by implication cannot have double descent. Eastern Indonesian examples are the Kodi of West Sumba (van Wouden 1977) and Lio of central Flores (Sugishima 1994). The classic example of parallel descent was the Apinayé of central Brazil described by the German Curt Unkel who adopted the Indian name Nimuendajú (1939). However Maybury-Lewis (1960) reanalyzed Nimuendajú's information and argued that Nimuendajú was mistaken. Da Matta restudied the Apinayé. Although he did not fully substantiate Maybury-Lewis's interpretation, he did confirm that they lack descent groups in which membership is determined by parallel descent (Da Matta 1973: 278; 1982). ${ }^{1}$ As for alternating descent, the only example was the Mundugumor of New Guinea as described by Mead (1935), but McDowell (1991) reviewed Mead's fieldnotes and revisited the Mundugumor and concluded that their fairly insignificant descent groups were patrilineal and

${ }^{1}$ Godelier cites two other societies with parallel descent: the Orokolo and the Ömie of Papua New Guinea. His source for Orokolo is Williams (1940). However, the ethnography consistently states that the Orokolo descent groups are patrilineal (Williams 1940: 25, 37, 43-45, 236), and I do not see on what grounds Godelier bases his characterization of them. In any case, see the comments by Maybury-Lewis (1960: 196-97) and Rohatynskyj (1990: 435). As for the Ömie, Rohatynskyj does not describe them as an example of the use of parallel descent for determining membership in a group, but as an example of differential sex affiliation associated with plant emblem identification. Lévi-Strauss (1949: 62; 1969: 49) refers to a different work by Williams than the one cited by Godelier concerning the Koiari of New Guinea as an example of parallel descent. Williams (1932: 53) describes Koiari males as belonging with exceptions to their father's groups and females with exceptions belonging to their mother's group. A few individuals were absorbed into a group which was neither that of the father or the mother. Williams (1932: 55) did not think that the word clan was applicable to these groups and they were not exogamous, a large majority of marriages taking place within the group. Furthermore, "In the ordinary case, informants will state that a daughter belongs to her mother's group; but the mother will say that she belongs to her mother's group, and this may prove to be quite a different one. If the classing of the daughter with the group of her mother were a matter of true descent, then a girl would belong to the group of her mother, grandmother, great-grandmother, etc. But obviously we are not dealing with descent in female children in the female line. The fact is that the girl is classed with her mother's father's group, or, what is the same thing, with the group of her maternal uncle" (Williams 1932: 58). Thus a female is classed with her mother's patriline. This is the reason that he chose to speak of "affiliation" rather than "descent" (Williams 1932: 75). In fact, "The daughter belongs to her mother's unit in the sense that she is expected to marry into it" (Williams 1932: 75-76, 80-81). Clearly therefore, the Koiari are also not an example of parallel descent, despite Lévi-Strauss's reference to them in these terms. 
that Mead had misrepresented the ethnography. The situation appears to be that in so far as substantial descent groups are concerned, two logical possibilities of descent rules, parallel and alternating, have no empirical examples.

There are other ways in which males and females may not end up in the same descent group. It is reported, for example, that among the Makassar and Bugis the even number children in birth order born to a couple are assigned to the father's group and the odd to the mother's, and a similar division occurred in Sumbawa in the case of a marriage between an aristocrat and a commoner when bridewealth had been paid, although these reports were not subsequently substantiated (Wilken 1912, vol. 1: 361-61, vol. 2: 212-13; Murdock 1940: 556; Maybury-Lewis 1960: 192, n. 4). This rule, however, would not result in a unilineal arrangement.

It has been common, particularly in Britain, to limit the term "descent group" to those collectivities in which membership is obtained by a unilineal rule. This tradition may be traced from Henry Sumner Maine via Rivers to Radcliffe-Brown and others. It was shared by persons with such diverse views as those of Fortes, Goody, and Leach, and was even endorsed by Dumont. Closely associated with this tradition was an interest in the corporate nature of such groups. Henry Sumner Maine asserted that prior to political association on the basis of local contiguity, kinship in blood was the only grounds for political union (1861: 124). Kinship for Maine, however, was determined by the question of authority. It should not be possible for a person to be subject to two distinct Patriae Potestates. Therefore, the family and higher order corporations must limit membership to agnates. In this way, it is possible to avoid conflict of laws in the domestic forum (Maine 1861: 145). For Rivers (1924: 86) descent groups were unilineal institutions where membership is "determined permanently and without option by the circumstances of birth." Leach (1962: 116) held that where, "descent does not in itself specify who is or is not a member of any particular group, it is ... misleading to describe the operative corporations as 'descent groups.", Dumont (1961: 25) argued that the simplest way to make dialogue possible between "descent theorists" and "alliance theorists" "would be to restrict 'descent' to what is in fact its most frequent use, i.e. membership in an exogamous group, and use another word, say, 'filiation' for the other cases."

Needham (1971: 10) suggested that we "cease concentrating immediately on substantive and jural aggregates of many kinds, exercising different functions, and ... think instead in terms of logical possibilities." This proposal, which might help Godelier advance some of his criticisms of Fortes and Goody but which he does not explicitly address, is a decisive break from the tradition reviewed above and needs to be seen in those terms in order to be understood. The result is that in any given society "different rights may be transmitted according to different modes," that is, such a society would be seen not monolithically as patrilineal, matrilineal, or what not, but as 
using the descent modes differently for different purposes and in a different configuration from another society with which under the older usages it might have been classed together (1971: 11). Following this recommendation we would cease to accord descent group membership its former privileged status in studies of descent. One consequence of this alternative approach is that one of the modes (parallel) which appears to lack empirical exemplification in respect of determining membership in substantive descent groups can be seen to be quite common for another purpose. In many societies it is normal for a man's tools to pass to sons and a woman's to daughters.

\section{A L LIANCE}

Godelier next takes up alliance as an alternative feature to descent. French alliance shares most of the same ambiguities as does English alliance, for example a political alliance between states or groups, as well as a marriage, particularly a bond between families resulting from marriage. In addition, "alliance" has come, under the influence of Lévi-Strauss, to take on a technical meaning relating to social institutions of certain non-Western societies. In French anthropological writing this technical sense is subservient to the broader usage, but in recent English-speaking writing, the technical sense seems to have predominated over the looser usage in which an alliance is merely a marriage. Reflecting the scope of his investigation, Godelier's use of alliance is much broader than the technical and often alliance is a synonym for mariage or even affinité. The difference between the French and the English usages is not great, but a native English-speaking anthropologist needs to keep an eye on the possibilities.

In that connection Needham (1986: 177) offers the following list of relevant meanings of the word alliance in the anthropological literature:

1. affinity between individuals or sets of siblings;

2. repeated intermarriage between groups;

3 . the consequence of a positive marriage rule;

4. an aspect of social structure as a system of relations of exchange;

5. the relationship established by bestowing and/or yielding a woman in marriage.

Godelier's chapter on alliance and residence begins expectably with Lévi-Strauss's classic contribution to the study of alliance, Les Structure élémentaires de la parenté (1949). ${ }^{2}$ Lévi-Strauss said that, "Properly speaking, then, this work is an introduction to a general theory of kinship systems" (1949: x; 1969: xxiv). Godelier sees Lévi-Strauss' object as opposing Radcliffe-Brown's emphasis on the fundamental importance of descent and putting in its place another principle, that of alliance which is founded

2 This book has gone through three quite distinct editions, each with significantly different wording (Lévi-Strauss 1949; 1967; and 1969). For ease of tracing these changes in wording consult Korn and Needham (1969). 
on exchange. For Lévi-Strauss the prohibition of incest is the origin of human society. There is a causal connection between the prohibition of incest, exogamy, and the exchange of women. Although formally, exogamous matrilineal descent groups could be seen as exchanging men, Lévi-Strauss insists that even in these cases, it is men who exchange women. For this position he has often been criticized, for example by Singer (1973, see also Holy 1996: 36-37), and Godelier (2004: 142) cites several empirical examples of the exchange of men, which also occurs occasionally among the cognatic Ngada of central Flores, in eastern Indonesia. ${ }^{3}$ Godelier concludes that the formula that "kinship is based on the exchange of women among men by men" is not universal. Hence, "the thesis of kinship as exchange would not, by itself, constitute the theoretical basis for the anthropological analysis of kinship." Today, Godelier states, there is no longer (as in the 1950s, especially in Britain) any attempt to assert the primacy of descent over alliance or alliance over descent. In European society today it is alliance (i.e., marriage) which is unwinding, while descent remains resilient.

\section{RELATIONSHIP TERMINOLOGIES}

Every society classifies relatives in one way or another. The Jesuit priest Lafitau (1724) found that the Iroquois had an utterly different way of reckoning family relations from Europeans. Morgan (1870) rediscovered the same facts and set out a worldwide exploration of their implications. Godelier argues that there are only a very small number of types of relationship terminologies and that all terminologies are independent of modes of descent. He begins with the terminologies used in western Europe, said to be Eskimo in which one term applies to father's brother and mother's brother, but not to father, and another to father's sister and mother's sister, but not to mother.

${ }^{3}$ Schröter (2000: 185) criticizes me for saying that in such cases a true groomwealth is paid and asserts that nowhere in the Ngada region does a groom price (Bräutigamspreis) exist and there is nothing which in the remotest sense could be so interpreted. She has simply not read the ethnographer carefully. Arndt (1954: 57) explicitly states that when a clan acquires one or more men who are willing to leave their own clan and join that of the woman a groomwealth is paid. "In einem solchen Falle wurde für den Mann an seine Sippe (Klan) „Bräutigamspreis“ gezahlt.” Her claim that my sympathetic comments on the situation of a man who has paid no bridewealth rests on a "projection" rather than empirical data overlooks the fact that I was simply characterizing Arndt's detailed description of the plight of such a figure (Arndt 1954: 70-71). She also accuses me of having described the Ngada as "fundamentally patrilineal with virilocal residence," whereas what I wrote is that, "The Ngada are a cognatic society with a segmentary clan system," that the segments of clans are marked by a special house composed of several extended families "descended from a common ancestral father or mother," that the, "Ngada have then large-scale corporate descent groups in which membership is determined solely by the system of marriage prestations," that, "There is no institution of unilineal descent," and that, "Clans and lineages may derive from male or female ancestors, and their members will be attached through male or female links" (Barnes 1972: 85; 1980: 112). I do not think she has yet presented the evidence which would establish that they have matrilineal descent groups of any kind, although there is no reason why some Ngada might not have them. 
This form of terminology was found in Rome from the second century A.D. and replaced a Sudanese terminology in which there were separate terms for father, father's brother, and mother's brother and for mother, father's sister, and mother's sister. The second Roman terminology replaced the local terminologies in Europe with the expansion of the Roman Empire. This history allows us to perceive that, "it is illusory to search for a direct causal relationship or even a structural correspondence between such and such a type of terminology and a given mode of production or political system" (Godelier 2004: 200).

The ancient Roman terminology classed mother as mater, mother's sister as matertera, and father sister as amita. It classed father as pater, father's brother as patruus, and mother's brother as avunculus. Avunculus was related to the term for avus, grandfather. Nepos reciprocated both avus and avunculus and applied to grandchildren and father's sister's children. Toward the end of the Roman republic, the term avunculus came to designate the father's brother as well, while patruus disappeared. Mother's sister became amita and matertera disappeared. A term meaning the children of two sisters (mother's sister's child), consobrinus, came to be applied to all four kinds of cousins, whence English "cousin" (Godelier 2004: 219; Benveniste 1969: 208, 255-66; Trautmann 2001: 276-77). In this way a "Sudanese" terminology became an "Eskimo" terminology.

One of the ways that terminologies differ is whether or not they have separate terms for affines from consanguines. Referring to features of the Dravidian terminology, Godelier argues that David Schneider is wrong to claim that to apply the term "consanguinity" in this sense to the Dravidian system is to impose a western representation of consanguinity and kinship. A great deal of effort in recent years has gone into comparison between the Dravidian systems and those of South America. Adopting an approach from Viveiros de Castro concerning the distinctions between cognation, consanguinity, and affinity, he argues that cognation is relatedness (that is, the recognition of a connection between two persons regardless of the nature of the kinship tie, or the rules of descent and definitions of affinity which may obtain). In the European "Eskimo" classification, cognation coincides with consanguinity, but not in Dravidian systems, where many cognates are affines categorically. Consanguinity and affinity are categorically defined and coincide only partially with genealogical relationships. Viveiros de Castro says that in some South American societies, affinity can become completely separated from genealogical ties. There are "pure" affines who are the ideal allies. These are distant strangers and enemies with whom one never exchanges women. Real affines become treated as consanguines. Affinity becomes pure representation and exists only in words. Different from India where, according to Dumont (1953), consanguines and affines are simply opposed to each other, some South American societies employ 
three concentric categories, consanguines, real affines, and pure affines. This transformation may have an origin outside of kinship. "We are here in the presence of societies where it is necessary to kill and absorb into oneself the flesh, soul or the name of an enemy in order to construct one's own identity and to increase one's prestige within one's own group, which was at the origin of the practice of cannibalism and the capturing of heads" (Godelier 2004: 235). Pure affinity without marriage is thinkable only with a cosmology in which war and the absorption of an enemy stranger becomes the equivalent of marriage and birth in the construction of individual and collective identity.

\section{THE CONCEPTION OF HUMANS}

Having quickly surveyed comparatively the differing functions of parenthood, Godelier, relying on Bernard Saladin d'Anglure, describes what it means to be an Inuit child. An infant given the name of a deceased kinsman or close associate of its parents makes him immediately live again and prolongs his real presence among his kin and friends. This custom produces a third sex. A mother frequently gives to a daughter the name of her deceased father in order to reincarnate the spirit and personality of its grandfather. She might also give it the name of a dead brother. Throughout its childhood this girl will be dressed and educated as a boy until her first menses when she must give up her male clothing. Boys may be treated similarly. At puberty they must kill their first game. Until puberty social sex may differ from physical sex. For its parents an Inuit infant is a bubble of air which it breathed at birth, a soul and double which grows with the child and survives its death in the place of the dead souls, its father's sperm become bone, its mother's blood, a face derived from its parents, a name which is also a soul and a moment on the cycle of reincarnation of soul-names in different people, a problematic sex, a powerful productive force acquired and accumulated by a long line of eponymous predecessors who have transmitted to it its name, animal flesh of game, an identity of "me" and "I" changing with the stages of its life, and a knot of life in the ball of thread which unrolls in time. 4 The sexual union of a man and woman is necessary for the birth of a child, but it is insufficient. Also required are the contribution of gods and of the dead who want to live again.

For the Baruya sexual union is necessary. The ability to do so was produced either by the sun and the moon or by the first woman. While the man provides the bone and flesh, the woman is merely a passive receptacle. The father not only plays the predominant role in manufacturing the body, he also connects the child to its ancestors by causing it to acquire a soul and giving it a name. The man and woman are thus not sufficient to produce a child by themselves. Young male initiates are dressed half as a boy half as a girl, with the posterior

\footnotetext{
4 "The thread of time is covered with knots" (Bachelard 1936: 67).
} 
left naked so that they cannot dare show themselves to women. The initiation attempts to remove all trace of the feminine from them, and they are forced into homosexual relationships. If a boy refuses for a long time, they will break his neck and tell his mother that he fell from a tree while hunting game. Repeated ingestion of sperm transforms the initiate's body into that of a man. Ritual flutes, according to legend stolen from the women, represent their creative power and are secretly called "vagina." In the presence of the sun the men collectively re-engender the initiates without women.

Contrary to the Baruya who ritually eliminate what kinship relations owe to women, for the Trobriand a dead person wishing to be reborn transforms itself into an infant spirit. The spirit of a woman's mother or other maternal relative or even of the woman's father makes the infant spirit penetrate the woman's body and make her pregnant. The decision to thus reincarnate belongs to the dead and not the living. The coming into being of a new human depends on two types of spirit, that of the dead and that of a living person, and the body of the woman, who though the genitrix is merely passive. The husband has no role as genitor. The husband's sperm plays no role in conception, but through repeated intercourse during pregnancy nourishes the fetus and transfers to it its father's features. Therefore the father is in fact necessary for the fetus to become a human being.

Godelier observes that while the lack of any contribution of the Trobriand father to conception has been seen as fitting the matrilineal rule of descent of Trobriand lineages, for the Nzema of Ghana who have matrilineal descent groups, the father plays a very important role. The blood in the infant's body and the soul which animates it derives from his sperm. The Maenge of New Britain have matrilineal clans and sub-clans. Here the husband's sperm alone manufactures the infant's body. The woman shares no substance with the child that she contains in her uterus and to which she gives an interior soul. ${ }^{5}$ The Tongans have two theories, according to the older of which sperm forms bone. The sperm mixes with menstrual blood and forms a clot. The woman's blood forms the flesh. The child however is the gift of the ancestors and the gods. According to the second theory the whole substance, flesh, blood, bones, skin, and hair, comes from the mother. The sperm merely blocks the menstrual blood in the uterus, forming a clot which turns into the embryo through the intervention of the gods or Tu'i Tonga. The father has in theory no role as genitor, a function reserved for Tu'i Tonga belonging to a royal lineage. Thus this lineage claims to be the fertilizer of all the women at the expense of commoner men. In Europe Christian theologians have represented marriage as a sacrament forming one flesh, but the union

\footnotetext{
5 The idea that doctrines about the contribution of the father and mother to creating the infant correlate with rules of descent must be wrong. The Ndembu of Zambia trace descent through the mother, but, "The mother is like a pot only, the body and soul of a child come from the father" (Turner 1967: 65).
} 
of a man and a woman is insufficient to make a child. The fetus they make requires a soul supplied by God during pregnancy. "Apparently, we are not so far from the man-god of the Tu'i Tonga of Samoa [sic. Tonga], who fertilizes with his spermic breath all of the women of the kingdom" (Godelier 2004: 301). For the Christian each soul is unique and a gift of God. That the soul of an individual is the reincarnation of another individual, an ancestor, is for Christian theologians an idea that must be opposed since it denies the systematic intervention by God in animating the body. To attack the cult of the ancestors is to attack the forms of social organization such as clans and lineages and was particularly unacceptable to the Chinese because it threatened not only the universe of kinship relationships, but also the fundamental pillars of the State. Thus, when the missionaries, influenced by the Dominicans, demanded that their flocks renounce the ancestor cult and destroy their domestic altars, not only did the people resist, but the Emperor immediately ordered the expulsion of the European missionaries.

Incest (such as the royal incest of the Tu'i Tonga), cannibalism, and the right to determine life and death for others distinguish sometimes the dominant from the dominated. For the Kako of Gabon, blood makes the flesh, bone, and breath. The spirits provide the soul toward the end of the pregnancy. The fetus is formed of a morsel of blood. During pregnancy the couple have intercourse to feed the fetus with the man's sperm and the woman's nourishment. If the man's blood is stronger than the woman's, the baby will be a boy, otherwise it will be a girl. Men always engender boys, women girls. The child is thought to be formed in equal parts of its father's and mother's blood linking it to its cognatic ancestors. The blood of the woman is however lighter. After the fourth generation uterine traces disappear. Only agnatic blood subsists. It is forbidden to marry into the clan of any one of the four grandparents. This theory, Godelier says, corresponds to the patrilineal descent groups. Because the feminine blood disappears after the fourth generation it becomes possible to renew marriage ties in the fifth. Allegedly these representations of blood correspond to the Omaha character of their kinship system, although this doctrine has nothing whatsoever to do with the Omaha. ${ }^{6}$ Female blood, for the Kako, is lighter because women do not practice war, do not hunt, and are forbidden to eat the meat and blood of cruel animals, which resembles that of men, and are excluded from the consumption of human flesh. Man is for the great hunters and warriors the game of first choice, "food" par excellence. For a man to have the right to eat a human, he needs to have killed many. Those who have fought, killed and eaten men were called "cruel" and they "hold the village" of which the chief can only be a great hunter, warrior, and eater of human flesh. The reproduction of

\footnotetext{
6 The existing ethnography simply does not give us the relevant information needed to know what their doctrines of conception were (see Fletcher and La Flesche 1911: 115-33).
} 
society seems to have been entirely in the hands of the cruel men, and blood symbolized the unity of society, since it is forbidden to eat a member of the tribe. But women possess considerable power expressed in the relation between brother and sister. Elder sisters assure the fecundity of the sistersin-law, and they conduct rituals to make their brother's fields fertile. They also ritually assure success of the brothers in hunting and warfare. They thus have spiritual and social power, which they may make felt by refusing to carry out the rites at the beginning of the dry season. While giving, through birth, children to another clan, they assure the continuity of their own by ritual means.

The chief of the Paici of New Caledonia is a stranger who must be sought in the bush, who must be transformed into an autochthon and who is transformed during his life into an ancestor by the "masters of the land." Periodically they feed him the flesh of a high-ranking man from his adopted lineage. Before the sacrifice, the funeral of the victim takes place, in the course of which the sacrificer tells the maternal uncles of the victim to take back his soul. The clan that furnishes the victim has considerable political weight and no decision can be taken without them. The chief's flesh was theirs. They act somewhat like his maternal relatives, being the containers of which he is the contents. The victims become ancestors in his body and turn him into an ancestor. The chief must also consume the flesh of one of his "father's sisters," women of the patrilineage of his supporters, who instead of exchanging their sisters for wives and increasing their alliances, consecrate some to make the chief more powerful. Autochthonized by endocannibalism, the chief can then destroy enemies, put them to flight, steal their women and children for adoption or exchange, consume the bodies of their warriors to annihilate them completely and prevent them from becoming ancestors, and hide their bones so that they cannot become relics. Conflicts within the chieftainship can be such that a chief may offer himself for sacrifice in order to save the chieftainship.

A myth concerning the Tu'i Tonga has him being engendered by a God with a daughter of a chief, then on a visit to his father in the sky and being devoured by his divine brothers. Discovered by their father, they are forced to vomit him up into a tree in which they have replaced the head for a divine rebirth. Both the Paici and the Tongan traditions present a figure who is born twice, once as a mortal, the second time as a man-god. The Mekeo of Papua New Guinea is an inverse example. At marriage and death they perform ritual deconception. The gods (and chiefs) on Tonga are cannibals. Only chiefs may eat human flesh and totally annihilate another human. Having gods as ancestors, having many wives, having the exclusive right to eat men, the chiefs are the only mortals who can look forward to living in paradise after death. In contrast with the Paici and the Tu'i Tonga, who become man-ancestor and man-god by cannibalizing humans, Mekeo chiefs affirm their divine essence and their 
legitimacy to govern by taking from their bodies all that remains of the feminine and giving it to others to consume.

In the West, Christ is a god who shared his flesh and blood with his faithful while affirming that he was born of a human woman who conceived without sexual union with a terrestrial husband. He is a god without a heavenly mother: "But whether one is a man made god (Tu'i Tonga) or a god made man, whether one 'grew' in cannibalizing others or in giving oneself to be consumed by others, it is always necessary subsequently that this exceptional being, inhuman or superhuman, prove that he has the right to devotion and submission by ordinary humans by giving them abundance, health, force, in short, life, or on the contrary removing the force, health, and life and annihilating them in anger. It is necessary that he give life or that he take it back in order to manifest his essence and divine power" (Godelier 2004: 323).

THE SEXED BODY

From the above, Godelier concludes that, "in no society are a man and a woman sufficient in themselves to make an infant." They make a fetus, but never a complete human. They do not supply the soul, which may be supplied by the dead, ancestors, spirits, or gods. In many societies, birth is not an absolute beginning and death is not the end of life. ${ }^{7}$ The ancestors often not being sufficient to transform a fetus into a human infant, the gods intervene. A child is everywhere a gift of the ancestors or the gods. The distinction between the soul (in Latin anima) and thought, intelligence (mens) is usually hardly theorized. The Latins distinguished between the anima and the mens and then reattached them. Christianity detached the mens from the anima and attached it to the spirit (spiritus), which was produced by the Holy Spirit. Although all societies accept the idea that certain children can be born without the mother having had sexual relations, they are always exceptional.

Because sexual access of parents to each other is independent of the social form of the appropriation of children, it forms, according to Godelier, the basis of the Oedipus complex, which may be supposed to be universal, thus showing Malinowski was wrong in accusing Freud of giving a definition to the Oedipus complex that only fit the patriarchical family of the Judeo-Christian societies of the West. In all ethnotheories of the individual and the process of creating him, the individual is inscribed in a social and cosmic totality that goes beyond the realm of kinship relations. The notion of consanguinity current in the West which designates as consanguines all of the paternal and maternal kin is not universal. This conception of consanguinity is derived from society and culture of the Latin peoples of ancient Rome. All the substances belonging to the sexed body and all their significance constitute the social attributes of

\footnotetext{
7 "Just as the man who has just expired is scarcely dead, the infant which has just been born is hardly alive" (Lévy-Bruhl 1910: 402).
} 
the sexes, transforming the sexes into genders, of which the roles and statuses differ while often being considered complementary. The complementarity of the genders does not prevent fundamental inequalities, which produce relationships of dominance and subordination between individuals depending on their sex. The imaginary representations of the body produce social institutions and symbolic practices which constitute the essential structures of society and thus have consequences that are not imaginary. Godelier holds that in all societies sexuality is put to the service of multiple realities-economic, political, and religious-which have nothing to do with the sexes or reproduction.

In an extraordinary flow of rhetoric, Godelier asserts that everywhere bodies and sexes act like ventriloquist's puppets which it is difficult to silence and which carry on conversations that do not come from them. It is precisely in the degree that sexuality is constrained to serve as a language to legitimate realities other than itself that it becomes a source of phantasms and imaginary universes. It is not sexuality which fantasizes society, but society which fantasizes in sexuality. It is not sexuality which alienates, but sexuality which is alienated. From being alienated, sexuality becomes then an instrument of alienation. The representation of the body determines in each society a sort of link of ideal social constraints which enchain the individual, which constitute the very social form of his intimacy. Sexuality deceives itself more than it deceives, and this ambivalence structures it.

PROHIBITION OF INCEST

All societies, Godelier tells us, prohibit a certain number of sexual practices. Indeed, he speaks of an ocean of prohibitions of which incest is only a particular case. The social order is not only a moral order and a sexual order, but it is also part of a cosmic order. From this fact the reasons invoked to prohibit and punish sexual practices are usually social, moral, and religious, that is at once real and imaginary.

Behind the Christian conception of incest lies the conception of marriage which was elaborated between the fourth and twelfth centuries, when marriage finally became a sacrament added to those of baptism and communion. This development led to the progressive multiplication until the twelfth century of a number of marriage prohibitions, applying to both consanguines and affines as well as to the spiritual parents through baptism. From the twelfth century the trend reversed and there was a progressive reduction in prohibitions to marriage, which continued in the twentieth century, at the end of which the prohibitions had been reduced to first cousins and immediate family relatives. The doctrine that marriage makes the husband and wife of one flesh derives from Genesis (2: 23-24). Just as by the sexual union of a man and woman, their affines become the equivalent of consanguines, godparents, by virtue of their spiritual union with their godchildren through baptism, 
also become equivalent to consanguines. By degrees all categories of relatives become in a certain way identical or almost, as more or less close forms of consanguines between whom sexual relations are prohibited. Throughout only a single principle applies. Thus in the Christian vision of incest, there is only one type, incest between consanguines extended to all categories of relatives viewed as equivalent to consanguines. There is then in the Christian kinship no room for incest of the "second type," as defined by Françoise Héritier. Héritier has argued that in addition to incest prohibitions of a first type-normally described as heterosexual relations between biologically (or sociologically) close relatives, but also including homosexual relations of the same kind-there is a second type of incest prohibitions concerning consanguines of the same sex, for example mother and daughter or two sisters, sharing the same partner. There is, she contends, greater shared substance, common identity, between same sex consanguines than opposite sex consanguines. Sexual intercourse involves the circulation of bodily fluids from one partner to the other. Incest of the second type leads to the transmission of identical humors from one consanguine to the other via the shared partner (Héritier 1994: 1125).

After the French revolution, civil marriage was imposed in several European countries, and it was often the only form of marriage recognized by law. Furthermore, marriage was no longer necessary, since the free union of two people was recognized and their children were as well. Divorce was recognized and widely practiced. Baptisms, marriages, and funerals in certain European countries from then on were private affairs. Only in the twentieth century, however, were the civil codes seriously modified in respect of the list of marriage prohibitions (Godelier 2004: 359). In Britain in 1907 it became legal for a man to marry a deceased's wife's sister, concluding a legal debate begun in 1842. From 1914 it became possible to marry the sister of a divorced wife (Héritier 1994: 117-39). A Baruya man would be astonished to be told that in having sexual intercourse with his wife he became of one flesh with her. A Trobriand woman would be equally astounded to learn that in having intercourse with her husband his blood became hers. In both cases the Christian doctrine contradicts their cultural representations and values. "Imagine the astonishment of a Baruya at the idea that his parents in engendering him had transmitted to him a sin which they did not themselves commit, but which was committed by the first human couple to exist on earth." For him sex is a source of disorder and pollution, but it is in no way a sin. In a religion of sin, individuals are guilty before being responsible. In Baruya religion, they are responsible before being guilty.

Godelier (2004: 367) contends that Héritier is wrong to argue that father/ daughter incest among the Ashanti of Ghana is incest of the second type because "the maternal substance is fully present in the daughter" (Héritier 1994: 186) and that in having sex with both the daughter and the mother, 
the father is putting the mother's substance in contact with itself. Godelier argues that the ethnographic situation in this case is that in fact the daughter has something of the father's substance which the mother does not share. "We are far from the primordial incest of mother and daughter, foundation of all prohibitions, source of trembling, etc., such as Françoise Héritier paints it" (Godelier 2004: 368).

Tylor (1889: 267) wrote, "Again and again in the world's history, savage tribes must have had plainly before their minds the simple practical alternative between marrying-out and being killed out." Despite the fact that Lévi-Strauss (1969: 19) denied arguments of Morgan and Frazer that exogamous systems incorporate methods for preventing incestuous unions and noted that such unions are only a small portion of those exogamous rules prevent, Leach (1970: 103) accused Lévi-Strauss, like Tylor, of regarding exogamy as the converse of incest prohibitions: "The fact is that in all human societies of which we have detailed knowledge the conventions governing sex relations are quite different from the conventions governing marriage so there is no case for saying that in the beginning the latter must have been derived from the former" (1970: 103-4).

Goody (1956) stated that Lévi-Strauss's theory of the incest taboo as the condition for the exchange of women and the establishment of relationships of alliance could not account for all the sexual prohibitions subsumed in the West under the term incest. Héritier subsequently also noted that LéviStrauss's theory could not account for incest prohibitions of the second type (Héritier 1994: 22-23). Héritier goes farther than Christian theologians in holding that the unity of flesh among kin makes consanguines of the same sex more identical than those of opposite sex. Godelier objects that the theological doctrine is actually that through intercourse the man and woman come to share the same flesh, as do their children. Thus the shared flesh could not be more identical between father and son and mother and daughter than between father and daughter and mother and son. Whereas for the theologians the substances of the couple become one, for Héritier, on the contrary, they remain distinct: "Briefly, from the moment where the identity of sex is posed as more fundamental than the identity between consanguines of different sex deriving from the same flesh, from the moment where the notion even of una caro as a mixture of substance has been replaced without theoretical justification by that of the transmission and placing in contact of humors, a new theory of incest emerges which has little to do with western Christian kinship, for which the theory claims however to be able to account" (Godelier 2004: 378-79).

For the Church, difference of sex is more importance than identity of sex. Heterosexual incest is more important than homosexual incest because heterosexual relations can give rise to life. For Héritier, despite much ethnographic documentation to the contrary, the most fundamental identity is that of sex and 
not consanguinity (Héritier 1994: 14). Godelier argues that Héritier's postulate has no universal value and accuses her of imposing a mechanical theory to which she gives greater reality than the particular local dogmas recorded by ethnography or theologians. Religion and morality become no more than after the fact rationalizations on this mechanical theory. Although Héritier denies reducing the subject of incest to a universal uniformity, "in the rest of the book this affirmation is absolutely contradicted" (Godelier 2004: 385). At the end of her book Héritier (1994: 353) takes the position that the most fundamental form of incest is that between mother and daughter. Because she argues that nature provided the most secret mechanisms to the ideal discrimination of the form and matter confused in the feminine sex, because all fetuses allegedly begin as feminine and half transform into males under the effect of a hormone, Godelier accuses her in the end of having resorted to a biological explanation of incest prohibitions and unveiling at last a pure fantasy of an ideal, non-incestuous, relationship between a daughter and her mother.

The Na of Yunnan province in western China have become notorious recently for having no marriage institution and for recognizing no role of husband or father (Cai 1997). In ancient Athens, a man would marry a dead brother's daughter, if she had no brother. In Roman Egypt between 15 and 20 percent of marriages were between full or half brothers and sisters (Hopkins 1980). ${ }^{8}$ Brother-sister marriage was the most valued and most sacred form of union for the ancient Iranians. Most ancient societies around the Mediterranean and in the Near East followed two strategies: marry as close as possible and a far away as possible. In the first case, their practices were the reverse of those later imposed by Christian theologians. These strategies meant that close marriage did not prevent the establishment of new alliances through distant marriages. They also challenge Lévi-Strauss' view that marriage is fundamentally alliance and that alliance implies the exchange of women. In Roman Egypt marriage could take place without exchange, while exchange could take place in the absence of an incest prohibition on the brother/sister relationship. The $\mathrm{Na}$, of course, circulate males among matrifocal households without marriage or formal relationships of alliance. Roman Egypt showed that being raised together did not suppress sexual desire. Freud appears to have triumphed over Westermarck, who suggested that familiarity erases sexual attraction. But the Egyptian case also appears to challenge Freud's theory of the repression of sexual urges arising within the family. Furthermore, although royal incest has been reported around the world, it has generally been taken as a sign of the exceptional position of kings, but in Egypt brother/sister marriage was practiced among the commonality.

\footnotetext{
${ }^{8}$ Shaw (1992), however, argues that these unions were the result of very special circumstances and should not be used to support general arguments about close kin marriage.
} 
For Freud the murder and cannibalization of the father was the origin of the incest prohibition. By making this prohibition the starting point for the exchange of women, he placed himself in a line of thought that includes Tylor, Reo Fortune, Leslie White, and Lévi-Strauss. He also committed himself to an imaginary and false history. However, Godelier (2004: 428) also takes the view that Freud took a great step in the understanding of man in his affirmation that all social order is at the same time a sexual order, by affirming that sexual desire divides men more than uniting them, by showing that because of this fact civilization requires controlling and repressing human sexuality, in emphasizing that human sentiments are ambivalent, that love contains hatred, and hatred love, and that the social order requires that hate, the desire to suppress the obstacle to the satisfaction of desire which culminates in the desire to murder, be repressed, by demonstrating finally that that which is repressed is not suppressed, nor does it disappear, but continues to exist and to manifest itself under other, socially acceptable, forms.

\section{EXCHANGE AND SOCIETY}

Godelier next turns to a long exposition of Lévi-Strauss' argument trying to establish that the incest prohibition gives rise to exogamy, which in turn gives rise to exchange of women. Of the three logical possibilities, men exchange women, women exchange men, or as in Euro-American and other cognatic societies, one family gives a man, the other a woman, and there is no question of one sex exchanging the other, Lévi-Strauss retains only the first. Godelier denies criticizing Lévi-Strauss either for considering male dominance to be universal, or for the idea that alliance rests often on the exchange of women between groups represented by men, but for the idea that the social subordination of women is based on unconscious structures of symbolic thought, in the last analysis on the structure of the brain, and that male dominance is the universal precondition of kinship relations. As opposed to Freud, Lévi-Strauss' interpretations immediately demonstrated the operational value and efficacy for a certain number of kinship systems. Lévi-Strauss devoted much less attention to the forms of descent, which are themselves highly specific cultural institutions, than to alliance. LéviStrauss' statement that, "the incest prohibition is less a rule which forbids marrying the mother, sister or daughter, than a rule which requires giving the mother, sister or daughter to another" (Lévi-Strauss 1969: 552), creates the illusion that these three forms of exchange are equivalent. Godelier knows of no examples of a man exchanging his mother in order to acquire a wife. Lévi-Strauss's assertion therefore does not engage with the facts. By leaving aside agonistic exchanges and inalienable goods, Lévi-Strauss neglects some of the most important aspects of political and religious power in society. 
Whereas in 1950, Lévi-Strauss took the position that "language could only arise at one go" and denied that it might appear gradually (Lévi-Strauss 1950: 16), by 1967 he had changed his position, and the sudden appearance of language had been replaced by a progressive evolution (Lévi-Strauss 1967: 451). On another point, too, Lévi-Strauss changed position. Human society no longer rested simply on exchange. Now in addition to things that were exchanged, there were things that were not exchanged, "Not that in society everything is exchanged,... but if there were no exchange, there would be no society" (Lévi-Strauss 2000: 494).

Whatever may remain of Lévi-Strauss's attempt to link exchange with the incest prohibition, Godelier (2004: 461-62) proposes an alternative view corresponding to six criteria:

1. It is necessary to separate the analysis of the prohibition of incest from the other prohibitions pertaining to sexual practices.

2. The prohibition of incest pertains to forbidden sexual unions before it does to prohibited marriage ties.

3. The prohibited sexual practices pertain to heterosexual and homosexual relations.

4. The prohibition of incest is found associated with prohibitions pertaining to relatives by alliance, either because the prohibitions pertaining to consanguines are "extended" to affines, or because prohibitions of another type apply to certain affines in complementing prohibitions pertaining to consanguines.

5. The prohibition of incest presupposes the development of conceptual thought and diverse means of communication, proto-languages and articulated languages. These developments did not appear as a Big Bang, but rather as a process taking place in the long extent of human evolution. These processes were for the most part unconscious, although the prohibitions themselves were conscious social facts. ${ }^{9}$

6. There is no reason to suppose that primitive humanity lived in isolated biological families (as assumed by Lévi-Strauss) or hordes (as assumed by Freud) before living in society. There is no reason to postulate for the distant ancestors of men and their descendants the logical or historical priority of consanguineous families living in a state of permanent sexual promiscuity rather than the development of proper forms of society.

To establish his own position on the evolution of society, Godelier turns to a long survey of modern studies of chimpanzees and bonobos, and he concludes that these animals live naturally in multimale and multifemale societies like

\footnotetext{
${ }^{9}$ We might usefully compare Donald's views on the development of human culture and cognitive evolution. Briefly, modern culture and the minds of individuals reflect the primate brain, plus three unique human layers, the mimetic, the oral-linguistic, and an external-symbolic layer. His central hypothesis is that over the past two and a half million years hominid cognitive evolution was increasingly tethered to culture. The first transition two million years ago accompanied tool use and a change of diet together with mimetic skill and expressive sounds before language. The second transition marks the arrival of archaic Homo sapiens, half a million years ago, accompanied by great changes in brain capacity and vocal tract, spoken language, and oral culture. Forty thousand years ago, the third transition began around a revolution in the technology of symbols and the externalization of memory. Cognition continued to evolve, driven by technology and culture (Donald 2001: 259-300). These interpretations seem to me compatible with those of Godelier.
} 
humans. These societies are characterized by the separation of the sexes and subordination of one sex to the other, and their sexuality includes heterosexual, homosexual, and autoerotic forms. There is no trace of primitive promiscuity among the chimpanzees and bonobos. These animals are able to act on nature in making tools and selecting food sources, but they cannot modify the organization of their society. Like other primates, humans did not give themselves society, but in contrast to them they developed the ability to transform their manner of living in society and to invent new forms of society.

Human beings produce society in order to live. Unlike chimpanzees and bonobos, humans do not leave the raising of children exclusively to females. In most human societies, males and females cooperate not only in raising children but in procreation of children. Human sexuality has pushed the distinction between the sexuality of desire and the sexuality of reproduction farther than is found in any other species of primate. Human sexuality is egoistic, but even extreme permissiveness must stop at the doors of the families, the groups which are directly responsible for raising children. Crossing these limits is to commit what is called "incest" (Godelier 2004: 491). It should be remarked that by saying so, Godelier is in effect proposing his definition of incest. Human families exist in two types. There are those composed solely of consanguines, such as the Na of Yunnan and the Nayar of Malabar, and those (the majority) structured by alliance (between husband and wife) and descent and filiation (between parents and children). Sexual permissiveness in the last case endangers not only ties of consanguinity, but also those of affinity. As demonstrated by reference to brother/sister marriage in Roman Egypt (which is similar to the behavior of gods), societies have two choices to make: (1) to marry without exchange or with; (2) to unite like gods or not like gods. There are no societies where marriage takes place only between very close relatives. Brother/sister marriage does not authorize other forms of close marriage or sexual relations. There is no society where an individual may satisfy all of his desires. Where close kin sexual unions prohibited in other societies are authorized in one society, such unions are not considered incestuous. They bring the couple closer to gods and take their legitimacy from a political and religious cosmology.

Godelier's (2004: 494-95) then lists twelve theoretical conclusions:

1. There is no society which permits individuals to satisfy all their sexual desires.

2. Two possibilities exist to assure the continuity of groups which make up a society which for survival depend on the birth of children who will continue their physical and social existence: to exchange between themselves sexual partners, generally women, but sometimes men, or not to exchange at all and to reproduce among themselves.

3. To exchange does not necessarily mean to form a marriage alliance. The exchange of substances is not an exchange of persons and does not transform itself into a social alliance (as in the case of the $\mathrm{Na}$ ). 
4. To form a marriage alliance does not necessarily mean to exchange, giving to others and receiving from others, but sometimes as well to keep for oneself and to ally among one's own group.

5. Everywhere where exchanges take the form of the exchange of persons and give place to diverse forms of alliance, the units of procreation and the raising of children combine ties of affinity and ties of filiation and descent, thus ties of consanguinity. Allies, by their union, engender consanguines.

6. Wherever there are unions resting on the exchange of persons and formalized by an "official" alliance, the sexual permissiveness authorized to individuals stops at the doors of the units of procreation and the raising of children. They are prohibited between the individuals of different sex and generation who make up these units and are considered as incestuous except if, on the other hand, they are regarded as unions making humans closer to gods.

7. In consequence, and logically, in the societies prohibiting sexual unions between near kin, humans are not authorized to imitate gods. Relations of humans with gods are invoked either to prohibit them or to permit relations between near kin. Unions among humans always bring into question the whole of society and cosmos.

8. There is no possible biological foundation to prohibiting sexual unions with the consanguines of affines or the affines of consanguines. Only social reasons could explain such prohibitions (which have no genetic consequences for the human species). It is necessary therefore for such unions to menace social cooperation and the ties of solidarity created between two groups of kin for them to be prohibited. However this situation indicates as well that the development of exchanges of partners giving place to alliances is a trait specific to human kinship.

9. No society known functions solely on the basis of endogamous unions between very close kin. Even in societies where such unions are authorized, other unions exist which obey other principles, unions with very distant consanguines or unions with non-kin, strangers; and these unions could themselves give rise to exchanges.

10. Even in societies where certain unions between close consanguines are not only authorized but sought after, other unions between consanguines are forbidden. It is necessary therefore to conclude that there exists no society that functions without one form or another of what is called the prohibition of incest.

11. The prohibition of unions between certain categories of consanguines is universal, but does not imply that the prohibition of the union of brother and sister is universal and that the exchange of women or men between two groups of kin should be everywhere the foundation of alliances.

12. The reciprocal giving of substances (sperm) between groups of kin does not necessarily produce alliance between groups.

Of all the inventions which have slowly separated humans from other primates and profoundly restructured the division of labor between men and women, one perhaps has more importance than the ability to manufacture and use tools and weapons, that is the domestication of fire. For men, unlike animals, fire is a weapon and a tool. Specifying the social conditions of sexual unions and the membership of the resulting children to groups were two problems which societies had to confront and resolve. Godelier proposes the hypothesis, contrary to Tylor and Lévi-Strauss, that our ancient ancestors already lived in families and that the very slow learning of new material and social relationships between the sexes created new 
relationships between adults and children as well as between groups where children were born and raised.

Man is the only animal species which has become co-responsible with nature for its own evolution. Humanity is the only social species which consciously and socially manages its sexuality. The two principles, to keep and to share, apply to all domains of life, including the provision of food. Even in the capitalist West not everything is available for sale. Societies and individuals are under two obligations, to exchange and to keep and transmit. Lévi-Strauss is wrong, Godelier says, to attempt to explain father's brother's child marriage among Arabs as an exchange of the right to keep, that is to keep marriage between close consanguines. (Lévi-Strauss 1988: 147). In this case the right to keep is distinct from the obligation to give.

Neither kinship relationships nor the family are the basis of society. Kinship relations, contrary to Fortes, are not necessarily the domain of the purest sentiments of altruism. They may also give rise to hatred and enmity. Kinship does not permit by itself creating a material and social dependence among all individuals and all groups in a society. It is no longer possible to claim that "primitive" societies, lacking castes, classes, and the state, were based on kinship. "But such a claim does not mean, as Leach would have it, that kinship is nothing but a language or a veil, or worse, an invention of anthropologists and therefore the West" (Godelier 2004: 517).

Chinese filial piety was a feudal imposition on domestic life and Australian section systems, far from being typical of Australia, spread only recently in western Australia and are primarily concerned with ordering even non-kin for ritual purposes. Social relationships having nothing to do with kinship penetrate kin relationships. The social becomes kin. First all that becomes kinship transforms into relations between the sexes, and finally all that is kinship impresses itself on the sexual body of individuals from birth and becomes an attribute of their sex. The difference of sex becomes a difference of gender.

THE WORLD TODAY

In his conclusion, Godelier notes that in the large population of the modern world, with its diverse universal and non-universal religions, spreading democracy, capitalism, and, one might add, education and modern health care and techniques of reproduction, kinship can be expected to continue to change, perhaps rapidly, and in diverse ways. The study of these transformations will require the efforts of scholars in many disciplines. After surveying issues of change in various parts of the world (Oceania, China, India, the Muslim world, sub-Saharan Africa), he returns to the changes in the West, particularly France, which he had identified in the introduction. In the West, as a result of the increase of divorce and increase of reconstituted or one-parent families a new form of kinship is emerging, where the union of 
individuals of opposite sex depends entirely on their own choice, where the family does not coincide with the couple, where the authority of the parents over children does not disappear nor does it diminish after the parents separate. Kinship within reconstituted families has nothing to do with adoption of children by adults who are not their parents, but with a kinship founded on a principle well known to anthropologists: parents are not necessarily those whose sexual union created the children, but are sometimes those who nourished and raised them.

In the West biological and genealogical ties have always been privileged. Social kinship unlinked to biological ties has occupied only a minor place, adoption, for example, having been forbidden by the Church for centuries. New reproductive technology has led to a partial dissociation between kinship and sexual relationships. In the case of sperm or egg donation or surrogate motherhood, three bodies become necessary for reproduction rather than two and the third person who has helped the other two is not regarded as kin to the child. In the case of reconstituted families the situation is the reverse. By marrying a divorced woman with children, a man who is also divorced and already has children of a previous union, acts as a social parent without having any legal status because he has no biological tie to his new wife's children. The converse is true for the new wife. Social kinship appears in this case without a legal status, because it lacks a biological basis.

Reproductive cloning is (still) prohibited. A second transformation is transsexual parentage. A third transformation is homosexual families. Godelier asks what would Freud or Lacan have said if told that the difference of sex was to disappear from the family? What has become of Lévi-Strauss' doctrine of men exchanging women if now men exchange men and women exchange women? How will a child with two mothers or two fathers construct his identity? How will such children be born? The legal reaction of Western countries to homosexual marriage and homosexual families has been various, but, "No law can from now on stop the movement" (Godelier 2004: 580). Godelier's position is that since it cannot be stopped, it is necessary to recognize it and to go along with it so that it acquires structures and legal limits acceptable to homosexuals and society. A permanent dialogue must be opened with those who want attention to their problems, requiring the participation of the most diverse representatives of society. What is at stake is the children born into and raised in homosexual families. The problem is not homosexuality but homoparenthood.

Homoparenthood has nothing to do with ethnographic examples such as woman-woman marriage among the Nuer (where the women in question do not have sexual relations) or Azande marriage between a warrior and an adolescent. It has been estimated that in Britain there are 20,000 children living in homosexual families, while in the United States 3,000,000 children have been so reported. Various studies in Britain and the United States indicate that such 
arrangements have slight or no effect on their eventual sexuality. In such families, a child will nevertheless have plenty of other contacts (relatives, friends, school mates) through which to discover the difference in sexes. "Homosexual parentage is no longer the door to hell or the insane asylum" (Godelier 2004: 586). Will homosexuality lead to heterophobia and discrimination against heterosexuals? When, for example, lesbians express an interest in sperm, but not the man who produced it, there is a risk of forgetting that the man is also a human being with a history and life. It is urgent to better understand the facts, to localize the problems, to open debates and to establish what decisions need to be taken politically, juridically, and socially to give individuals new rights and to identify legal responsibilities going with them.

The finding of thirty-two skeletons of Homo Heidelbergensis from 300,000 years ago in a cave in Sierra d'Atapuerca in Spain, near one of whom was placed a biface of red quartz, confirms for Godelier his hypothesis that relationships of kinship appeared before articulated language and that the imagination of an afterlife also preceded it. Archaeologists have also discovered later grave sites associated with Neanderthal populations and CroMagnons, showing that kinship relationships, beliefs in the afterlife, and symbolic rites appeared twice in two species of men who evolved in parallel, but of which one eventually disappeared. Kinship relationships are not about to disappear. Their disappearance would be the annihilation of what is specific to man, that which separates him definitively from the other primates.

\section{FINAL ASSESSMENT}

The preceding précis of this long and complex book has left a great deal out, including in particular much of Godelier's lengthy discussion of relationship terminologies. The book contains many loose ends and some blind spots, but Godelier has set his ambitions very high and has put an enormous amount of work into trying to match them. He has attempted to demonstrate that kinship continues to be important in today's societies both East and West and that it will continue to require the attention of those disciplines which devote themselves to human activities. Godelier (2004: 363) says that we can speak of the universality of the incest prohibition only in a relative sense because the prohibition and non-prohibition of incest are two complementary principles necessary to the functioning of society, but has not directly addressed the possibility that all that is common to incest prohibitions may be the feature of prohibition itself (Needham 1971: 29).

Some readers will find some of his generalizations overdone and some of his metaphors stretched beyond the point of credibility. Whether all of his historical and ethnographic interpretations and facts will be found acceptable to the experts remains, to my mind, an open question. An underlying theme is that biology, particularly sexuality, is important to kinship. This theme constitutes somewhat more than an implicit assault on the distinction between 
biology and the social in respect of kinship relations. Whether he has actually adopted a position that is different from that of those who wish to maintain the distinction is unclear to me. The biological facts have never, to my knowledge, been thought irrelevant. Finally the impressive theology of conception he has found in society after society exceeds in depth and clarity of development anything I have encountered in other societies. I wonder though whether such a theology has equal importance in all societies and whether therefore doctrines of conception merit the general explanatory importance they have in this book. Whatever may be said in criticism, Godelier has reasserted the value of our rich tradition of discussions of kinship matters. He has also shown how the category has metamorphosed as it has drawn in new issues of pressing current importance in modern life and made his case that, far from being genuinely in decline, the study of kinship is central to our understanding of what it means to be human.

\section{REFERENCES}

Arndt, Paul. 1954. Gesellschaftliche Verhältnisse der Ngadha. (Studia Instituti Anthropos 8) Wien-Mödling: Verlag der Missionsdruckerei St. Gabriel.

Bachelard, Gaston. 1936. La dialectique de la durée. Paris: Boivin.

Bamberger, Joan. 1974. Naming and the Transmission of Status in a Central Brazilian Society. Ethnology 13, 4: 363-78.

Barnes, R. H. 1972. Ngada. In, Frank M. LeBar, ed., Ethnic Groups of Insular Southeast Asia. New Haven: Human Relations Area Files Press.

- 1980. Marriage, Exchange and the Meaning of Corporations in Eastern Indonesia. In, J. L. Comaroff, ed., The Meaning of Marriage Payments. London: Academic Press.

Benveniste, Émile. 1969. Le Vocabulaire des institutions indo-européennes: 1. économie, parenté, société. Paris: Les Éditions de Minuit.

Cai Hua. 1997. Une société sans père ni mari: Les Na de Chine. Paris: Presses universitaires de France.

Da Matta, Roberto. 1973. A Reconsideration of Apinayé Social Morphology. In, Daniel R. Gross, ed., Peoples and Cultures of Native South America. New York: Doubleday/The Natural History Press.

—. 1982. A Divided World: Apinayé Social Structure. Cambridge: Harvard University Press.

Donald, Merlin. 2001. A Mind So Rare. New York. W. W. Norton.

Dumont, Louis. 1953. The Dravidian Kinship Terminology as an Expression of Marriage. Man 53, 54: 34-39.

- 1961. Descent, Filiation and Affinity. Man 61, 11: 21-25.

Fletcher, Alice C. and Francis La Flesche. 1911. The Omaha Tribe. (Annual Report of the Bureau of American Ethnology, vol. 27.) Washington, D.C.: Government Printing Office.

Forde, Daryl. 1950. Double Descent among the Yakö. In, A. R. Radcliffe-Brown and Daryll Forde, eds., African Systems of Kinship and Marriage. London: Oxford University Press.

Fortes, Meyer. 1953. The Structure of Unilineal Descent Groups. American Anthropologist 55, 1: 17-41. 
1959. Descent, Filiation and Affinity: A Rejoinder to Dr. Leach: Part II. Man 59, 331: 206-12.

Geertz, Hildred and Clifford Geertz. 1975. Kinship in Bali. Chicago: University of Chicago Press.

Godelier, Maurice. 2004. Métamorphoses de la parenté. Paris: Fayard.

Goody, Jack. 1956. A Comparative Approach to Incest and Adultery. British Journal of Anthropology 12, 1: 286-305.

Héritier, Françcoise. 1994. Les deux sœurs et leur mère. Paris: Éditions Odile Jacob.

Holy, Ladislaw. 1996. Anthropological Perspectives on Kinship. London: Pluto Press.

Hopkins, Keith. 1980. Brother-Sister Marriage in Roman Egypt. Comparative Studies in Society and History 22: 303-54.

Korn, Francis and Rodney Needham. 1969. Lévi-Strauss on the Elementary Structures of Kinship: A Concordance to Pagination. London: privately printed.

Lafitau, Joseph Françoise. 1724. Moeurs des sauvages ameriquains, comparées aux moeurs des premiers temps. 2 vols. Paris: Saugrain.

Leach, E. R. 1962. On Certain Unconsidered Aspects of Double Descent Systems. Man 62, 214: 130-34.

1970. Lévi-Strauss. London: Fontana/Collins.

Lévi-Strauss. 1949. Les Structure élémentaires de la parenté. Paris: Presses Universitaires de France.

. 1950. Introuduction à l'oeuvre de Mauss. In, Marcel Mauss, Sociologie et anthropologie. Paris: Presses universitaires de France.

— 1967. Les Structure élémentaires de la parenté. (Collection de Rééditions.) The Hague: Mouton.

- 1969. The Elementary Structures of Kinship. Rev. ed. J. H. Bell, J. R. von Sturmer, and R. Needham, trans.; Rodney Needham, ed. Boston: Beacon Press.

1988. De près et de loin. Paris: Odile Jacob.

2000. Apologue des amibes. In, Jean-Luc Jamard, Emmanuel Terray, and Margarita Xanthakou, eds., En substances: textes pour Françoise Héritier. Paris: Fayard.

Lévy-Bruhl, Lucien. 1910. Les Fonctions mentales dan les sociétés inférieures. Paris: Alcan.

Maine, Henry Sumner. 1861. Ancient Law. London: John Murray.

Maybury-Lewis, David. 1960. Parallel Descent and the Apinayé Anomaly. Southwestern Journal of Anthropology 16, 2: 191-216.

McDowell, Nancy. 1991. The Mundugumor: From the Field Notes of Margaret Mead and Reo Fortune. Washington, D.C.: Smithsonian Institution Press.

Mead, Margaret. 1935. Sex and Temperament in Three New Guinea Societies. New York: Morrow.

Morgan, Lewis Henry. 1870. Systems of Consanguinity and Affinity of the Human Family. (Smithsonian Contributions to Knowledge, no. 218.) Washington, D.C.: Smithsonian Institution.

Murdock, George Peter. 1940. Double Descent. American Anthropologist 42, 1: 555-61. . 1949. Social Structure. New York: Macmillan.

Needham, Rodney. 1971. Remarks on the Analysis of Kinship and Marriage. In, Rodney Needham, ed., Rethinking Kinship and Marriage. (A.S.A. Monographs 11.) London: Tavistock. . 1986. Alliance. Oceania 56, 3: 165-80.

Nimuendajú, Curt. 1939. The Apinayé. Robert H. Lowie and John M. Cooper, eds., Robert H. Lowie, trans. (Catholic University of American Anthropological Series, no. 8.) Washington, D.C., The Catholic University of America Press. 
Radcliffe-Brown, A. R. 1952. Patrilineal and Matrilineal Succession. In Structure and Function in Primitive Society: Essays and Addresses. London: Cowen and West.

Rivers, W.H.R. 1924. Social Organization. W. J. Perry, ed. London: Kegan Paul, Trench Trubner.

Rohatynskyj, Marta. 1990. The Larger Context of Ömie Sex Affiliation. Man 25, 3 : 434-43.

Scheffler, Harold W. 2001. Filiation and Affiliation. Boulder, Colo.: Westview Press.

Schneider, David. 1972. What is Kinship all About? In, Priscilla Reining, ed., Kinship Studies in the Morgan Centennial Year. Washington, D.C: Anthropological Society of Washington.

Schröter, Susanne. 2000. Die Austreibung des Bösen: Ein Beitrag zur Religion und Sozialstruktur der Sara Langa in Ostindonesien. Stuttgart: Kohlhammer.

Shaw, Brent D. 1992. Explaining Incest: Brother-Sister Marriage in Graeco-Roman Egypt. Man 27, 2: 267-99.

Singer, Alice. 1973. Marriage Payments and the Exchange of People. Man 8, 1: $80-103$.

Sugishima, Takashi. 1994. Double Descent, Alliance and Botanical Metaphors among the Lionese of Central Flores. Bijdragen tot de Taal-, Land-en Volkenkunde 150, 1: $146-70$.

Terray, Emmanuel. 1969. Le Marxisme devant les sociétés «primitives»: Deux études. Paris: François Maspero.

1972 Marxism and "Primitive" Societies. New York: Monthly Review Press.

Trautmann, Thomas R. 2001. The Whole History of Kinship Terminology in Three Chapters: Before Morgan, Morgan, and After Morgan. Anthropological Theory 1, 2: $268-87$.

Turner, Victor. 1967. The Forest of Symbols: Aspects of Ndembu Ritual. Ithaca: Cornell University Press.

Tylor, E. B. 1889. On a Method of Investigating the Development of Institutions; Applied to Laws of Marriage and Descent. Journal of the Anthropological Institute 18: $245-72$.

Wilken, G. A. 1912. Verspreide Geschriften, vols. 1 \& 2. The Hague: van Dorp.

Williams, F. E. 1932. Sex Affiliation and Its Implications. Journal of the Royal Anthropological Institute 62: 51-81.

. 1940. Drama of Orokolo: the Social and Ceremonial Life of the Elema. Oxford: Clarendon Press.

Wouden, F.A.E. van 1977. Social Groups and Double Descent in Kodi, West Sumba. In, P. E. de Josselin de Jong, ed., Structural Anthropology in the Netherlands. (Translation series-Koninklijk Instituut voor Taal-, Land- en Volkenkunde, 17.) The Hague: Nijhoff. 